\title{
Assessment of Government Incentives for Energy from Waste in Colombia
}

\author{
Santiago Alzate-Arias ${ }^{1}$ (i), Álvaro Jaramillo-Duque ${ }^{2, *(1)}$, Fernando Villada ${ }^{2}$ (i) and \\ Bonie Restrepo-Cuestas 1 (iD \\ 1 Research Group in Advanced Materials and Energy (MATyER), Instituto Tecnológico Metropolitano, \\ Calle 54A No. 30-01, Medellín 050013, Colombia; sanalz393@gmail.com (S.A.-A.); \\ bonierestrepo@itm.edu.co (B.R.-C.) \\ 2 Research Group in Efficient Energy Management (GIMEL), Faculty of Engineering, Department of Electrical \\ Engineering, Universidad de Antioquia, Calle 67 No. 53-108, Medellín 050110, Colombia; \\ fernando.villada@udea.edu.co \\ * Correspondence: alvaro.jaramillod@udea.edu.co
}

Received: 25 February 2018; Accepted: 19 April 2018; Published: 23 April 2018

\begin{abstract}
This work evaluates the prefeasibility of energy from waste projects in Colombia under the guidelines of Law 1715. That piece of legislation proposes tax incentives for non-conventional energy initiatives, such as deductions of up to $50 \%$ on the investment through income tax, VAT exemption, tariff exemption, and accelerated depreciation of assets. Pasto, Colombia, was selected as the case study. Subsequently, incineration, gasification, anaerobic digestion, and landfill gas technologies were evaluated. The potential of electric power generation from municipal solid waste (MSW) of each conversion technology was estimated with mathematical models. Additionally, the economic evaluation considered five cases that combine loan options, accelerated depreciation, and income deductions. Finally, the prefeasibility analysis of each case and technology was based on the internal rate of return (IRR) and levelized cost of electricity (LCOE). The results reveal that only anaerobic digestion and landfill gas technologies constitute viable projects in case of traditional investment with and without loans, because they present IRRs greater than the discount rate, of $6.8 \%$. However, by including the incentives in Law 1715 in the economic evaluation, IRRs of $11.18 \%, 7.96 \%, 14.27 \%$, and $13.59 \%$ were obtained for incineration, gasification, anaerobic digestion, and landfill gas, respectively. These results make all four technologies feasible in this context.
\end{abstract}

Keywords: energy policies; waste-to-energy; municipal solid waste; levelized cost of electricity; internal rate of return

\section{Introduction}

The accelerated growth and high socioeconomic development of the world's population in the last decade have caused an enormous impact on the production of municipal solid waste (MSW) [1,2]. The population of cities and per capita income are decisive factors in the generation of solid waste [3]. Currently, companies responsible for waste management do not take full advantage of the energy potential there is in waste. However, said recovery is known to be possible with thermal conversion technologies (incineration and gasification) and bioconversion (landfill gas and anaerobic digestion), which have been successful in some countries [4,5]. These solutions, besides enabling optimal waste management, contribute to meet the energy demands of the country.

For instance, in the Kingdom of Saudi Arabia, the government started the King Abdullah City of Atomic and Renewable Energy (KACARE) in 2010 to maximize the use of science, research, and promote industries related to atomic and renewable energy. For that reason, Ouda, Cekirge, Huseyin 
and Raza [6] assessed the potential contribution of WTE facilities to total Saudi peak power demand up to the year 2032 by means of a quantitative analysis in six major cities. In that study, the MSW production rate was assumed to be an average $1.4 \mathrm{~kg} /$ capita/day. Furthermore, a financial model to assess the viability of WTE investments in Saudi Arabia was proposed by Hadidi and Omer [7] in order to address the waste management challenges and meet the forecasted energy demands. Gasification and anaerobic digestion (AD) were analyzed using financial indicators, i.e., net present value (NPV), internal rate of return (IRR), modified internal rate of return (MIRR), profitability index (PI), payback period, discounted payback period, levelized cost of electricity (LCOE), and levelized cost of waste (LCOW).

In Africa, Tanzania faced a serious problem regarding MSW disposal, which prompted the creation of the Taka (waste) Gas Project. This strategy is designed to utilize organic solid waste from the city of Dar es Salaam for producing biogas and, ultimately, generating electric energy. Additionally, Moreno [8] defines some actions to implement such a project and make it feasible.

The work in [4] assessed the WTE potential of municipal solid waste (MSW) throughout Nigeria. The country's annual electricity generation potential from MSW was estimated to be $26,744 \mathrm{GWh}$ /year. In this nation, $89 \%$ of the states have the capacity to generate at least $50 \mathrm{MW}$, which is the minimum regulatory limit imposed by the government. This fact confirms that this type of analysis is important for enabling the introduction of policies that foster WTE technologies.

In some Latin American and Caribbean countries, the current capacity of sanitary landfills has been exceeded. As a result, MSW management was identified as a global sustainability challenge [9].

MSW is considered to be a renewable energy source. In Colombia, Mexico, Argentina, and Chile, regulations stipulating incentives for electric power generation from non-conventional renewable energy sources (NCRE) have been developed [10]. In Argentina, Law 26.90 of 2015 defines landfill gases and biogas as a NCRE. Mexico, within the legal framework of renewable energy, considers the organic components of municipal solid waste and other sources of organic waste to be types of renewable energy sources. Chile includes the biodegradable fraction of solid waste in the national list of non-conventional renewable generation methods [11-13].

This overall picture suggests that the conversion of waste to energy is deemed a comprehensive solution to manage waste appropriately and meet energy demands. Nevertheless, this scenario requires a regulatory framework that promotes NCRE projects with economic benefits.

Energy recovery from solid waste (SW) is considered to be a renewable energy source in Colombia, in accordance with Law 1715, Section 18, enacted by the Congress of the Republic of said country [14]. The same act offers incentives for new NCRE projects, which represent a reduction of up to $50 \%$ over the total value of the investment through income tax. In addition, there are other measures, such as VAT and tariff exemptions, and accelerated depreciation of assets (e.g., national or imported equipment, tools, machinery, and services) for the production and use of energy from NCRE.

According to the Colombian Superintendence of Domiciliary Public Utilities (SSPD, for its acronym in Spanish) 1102 municipalities generated 26,528 T/day of solid waste in 2014. A total of $80.4 \%$ of that waste was disposed of in sanitary landfills, $3.09 \%$ was used in recovery plants, and $1.27 \%$ was taken to containment buildings. The regulations in force (Decree 838 of 2005, Decree 2820 of 2010, and Resolution 1890 of 2011) prohibit the waste disposal methods adopted for the remaining SW in the country: release into bodies of water $(0.45 \%)$, uncontrolled burning $(0.18 \%)$, garbage dumps $(10.34 \%)$, and temporary trenches $(4.26 \%)$ [15].

This study aims to evaluate the impact of the tax benefits of Law 1715 of 2014 on the economic analysis of projects in the field of electric power generation from MSW. To carry out this evaluation, the study was divided into three stages: (1) The city of Pasto was chosen as the study case because its number of inhabitants is close to the average of urban centers in the country; (2) afterwards, the energy potential from SW was estimated with four technologies of conversion to electric power; and (3) The economic prefeasibility evaluation included the benefits established by Law 1715, e.g., accelerated depreciation of assets and income tax exemption. Finally, considering the aforementioned incentives, 
the internal rate of return (IRR) and levelized cost of energy (LCOE) were calculated for each type of technology. In this context, the prefeasibility study enables an early analysis to evaluate the potential of WTE projects in Colombia. The results will contribute to collect basic information to make the decision to continue with more detailed studies and verify if a project is profitable or not.

\section{Conversion Technologies}

Waste to energy conversion involves thermochemical and biochemical processes. Thermochemical treatment methods are widely preferred due to the substantial reduction of waste volume, the destruction of pollutants, and the opportunity they offer to recover materials and chemical products. The most commonly-used thermochemical treatment is incineration; however, newer technologies, such as pyrolysis and gasification, are more efficient and emit less greenhouse gases [4,16]. Biochemical conversion processes include recovery of gas from landfills, anaerobic digestion, fermentation, and anaerobic composting [7,17]. They use microorganisms that decompose solid waste, sludge, or gas by turning the chemical energy in the SW into high-energy value products, such as methane $[4,18]$. The following is a brief description of the thermochemical and biochemical processes mentioned above.

\subsection{Incineration}

This method directly burns the SW in the presence of excess oxygen at temperatures above $800{ }^{\circ} \mathrm{C}$ [19]. Last-generation incineration plants are characterized by the high performance of the chemical conversion process and maintaining the emissions within the levels allowed by environmental regulations. Nowadays, modern plants can be considered efficient units for destroying dangerous organic substances and recovering energy and materials [9].

After the energy crisis in the 1970s, SW incineration techniques were quickly developed in countries like Japan, Denmark, Sweden, Switzerland, China, Spain, and Austria [9,20]. The great majority of these WTE plants are based on moving grate combustion of as-received or post-recycled MSW, and produce electricity and heat [21].

In countries like Spain, Malaysia, and Brazil, the viability of obtaining energy from incineration has been analyzed with positive results [22-24].

One of the main advantages of this technology is that it can treat organic and inorganic waste alike. As a result, waste volume can be reduced up to $80 \%$ [20]. The plant enables continuous feeding and treatment is fast. It can save space and reduce some greenhouse gases, e.g., methane [25]. The complexity of the plant is low, and it can be located in urban areas if all the technical and environmental requirements are met. There are some disadvantages as well; it is not viable to build plants for volumes under $100 \mathrm{~T} /$ day of SW and the chemical production of dioxins must be considered. Additionally, this technique is not appropriate for SW with high contents of humidity and low calorific value [26,27].

\subsection{Gasification}

Gasification is defined as the thermochemical conversion of materials that contain carbon into synthesis gas by means of reactions in an oxygen-deficient atmosphere using gasifying agents, such as air, hydrogen, vapor, and their mixes [7]. During the process, a certain amount of methane and other higher hydrocarbons are generated depending on the design of the reactor and its operating parameters. The resulting synthesis gas can generate electricity with combustion engines, and it is potentially more efficient than the direct combustion of the original fuel because it can be burned at higher temperatures or even in fuel cells [21].

Although gasification technologies can process unclassified SW, their efficiency increases when it is classified. This work assumes that the SW provided to the gasification facility is processed by a mechanical system that eliminates all the recyclable and inorganic materials [7].

In Colombia, there is a small-scale project in the Municipality of Necoclí (Antioquia). This $40 \mathrm{~kW}$ plant generates power by gasifying biomass in the form of two-inch wood cubes which, when subjected to high temperatures with a controlled amount of oxygen, produce lean gas that is injected into a 
conventional engine-generator [28]. An analysis developed in Brazil enabled establishing the amount of electricity obtained from SW gasification in different population scenarios [29].

The main advantages of gasification are related to the fact that it is relatively faster than the other conventional processes. As a result, more waste can be treated in less time [30]. This technology may prevent the formation of dioxins and reduce the emission of acid gases [31]. Additionally, the waste volume can be reduced between $50 \%$ and $90 \%$ and the plant requires little land for construction; it can be located in industrial and urban areas. One disadvantage is that the net energy recovery can be low in the presence of waste containing excessive humidity. Another drawback is that the complexity of the process is relatively high [7].

\subsection{Anaerobic Digestion}

Anaerobic digestion $(\mathrm{AD})$ is a bioconversion process where the organic components of SW are treated to create a gas rich in methane $(65 \%)$ and carbon dioxide $(35 \%)$ called biogas [7,32]. This mixture of combustible gases is produced by the anaerobic fermentation of the biomass caused by bacteria. It takes several days to form, and the process is carried out in an oxygen-deficient atmosphere. The main sources of biogas are household garbage, manure fermentation, and untreated residential wastewater. In addition to methane and carbon dioxide, biogas also contains small amounts of hydrogen sulfide and some other pollutants that can be controlled [33].

AD has been implemented in countries like France, who managed to produce $660 \mathrm{GWh}$ of electricity from biogas by the end of 2009 [34]. In Colombia, the Chicón project in Chigorodó (Antioquia) was in its construction stage as of 2016; this projects seeks to produce $2 \mathrm{Mm}^{3}$ of biogas and $500 \mathrm{~kW}$ of electric power from 15,000 T/year of organic SW [8,35-37].

Some authors have evaluated the energy recovery potential of biogas from anaerobic digestion to generate electric or thermal energy in Spain, Brazil, China, and Tanzania [38-40]. This type of technology is profitable and applicable to a production greater than $2 \mathrm{~T} /$ day of SW. It must only be fed the organic fraction, which means waste sorting is necessary. However, this process avoids greenhouse gases and its digestate, rich in nutrients, can be used as organic fertilizer. Additionally, in small-scale plants, the co-digestion of raw material or SW can be performed with biosolids. Still, the resulting biogas must be treated for final use. The complexity of this type of plants is low and they are usually located in rural areas $[27,38,39]$.

\subsection{Landfill Gas}

Abbreviated as LFG, it mainly comes from the anaerobic decomposition of the biodegradable fraction of MSW disposed of in sanitary landfills. Particularly, biogas production starts after the disposal of MSW and gradually rises during a period of time that depends on the composition of the MSW, the climate, and the features of the location of the sanitary landfill [41].

LFG is usually $50 \%$ methane and $50 \%$ carbon dioxide. This gas is extracted from drilled wells with pipes inside landfills and later burned to produce electricity [18]. The mean recovery rates of biogas range from 120 to $150 \mathrm{~m}^{3} / \mathrm{T}$ of MSW, which is equivalent to a $2.5 \mathrm{MJ} / \mathrm{kg}$ calorific value [17]. Specifically, the amount of biogas needed to generate $1 \mathrm{MWh}$ of electricity is between 550 and $600 \mathrm{~m}^{3}$ [42]. A total of $0.78 \mathrm{MW}$ could be produced per ton of MSW, thus generating from 6500 to 10,000 MWh a year [42].

Due to the improvement of air quality and the mitigation of greenhouse gas emissions, the use of technologies to recover electric power from LFG has been successful in many countries. For example, in 2007 Taiwan had four facilities capable of generating $25 \mathrm{MW}$ from biogas produced at four sanitary landfills [41]. Israel is another country that produces electricity from LFG. In 2006, a direct biogas-burning system was replaced by a power generation system that provides the national grid with 1.4 MWh [42].

This technology has been implemented in Colombia as well, and it has been successful. About $640 \mathrm{kWh}$ are being generated from the biogas produced at the Doña Juana sanitary landfill in Bogotá [43], and there are plans to increase said generation. Additionally, the municipal waste 
management company in Cúcuta is implementing (in 2017) this technology to generate 2 MW from the 851 tons of MSW that are disposed daily into the Guayabal sanitary landfill and from the metropolitan area of Cúcuta [44].

Gas from sanitary landfills is a low-cost option to produce electric or thermal energy, although its efficiency reaches only $30 \%$ or $40 \%$ of the total gas generated. The level of complexity of this type of plant is low; hence, they do not require qualified staff for their operation. One of their disadvantages is the large area they require to be operated. Additionally, spontaneous combustion might occur as a result of the accumulation of methane gas, and surface runoff during rains causes the soil and groundwater to be contaminated by lixiviates [27,38-40].

\section{Materials and Methods}

The effect produced by the tax incentives in Law 1715 was assessed in three stages: (1) analysis of the waste produced in the municipality; (2) evaluation of the energy recovery potential of different technologies; and (3) economical evaluation of each technology. Firstly, per capita production (PP) of waste and its physical characterization were obtained (see Section 3.1). This information is available online in the solid waste management plan of the Municipality of Pasto [45].

Later, to calculate the energy potential, four technologies were considered: incineration, gasification, anaerobic digestion, and landfill gas recovery. Such potential was calculated by means of the mathematical models described in Section 3.2.

Finally, the economical evaluation was based on the calculation of IRR and LCOE in the five cases proposed in Section 3.3, with and without tax incentives.

\subsection{Analysis of Pasto's MSW}

In Colombia, $60 \%$ of the population lives in 62 municipalities with more than 100,000 inhabitants. The average of inhabitants in those 62 towns is $470,041.11$, approximately the number of inhabitants in Pasto: 440,040 (2015) [46]. This city presents an urban population index (UP) of 0.2 , which means it is clearly urban. The UP is the quotient of the number of inhabitants between rural and urban areas in a given municipality [47]. The area of this administrative division is $1128.4 \mathrm{~km}^{2}$ and the urban territory covers $26.4 \mathrm{~km}^{2}$. It is officially called San Juan de Pasto, located in Southwest Colombia, and the capital of the Department of Nariño. Its precise location is $01^{\circ} 12^{\prime}$ north latitude and $77^{\circ} 16^{\prime}$ west longitude in the middle of the Andes mountain range, in the mountain massif named Nudo de los Pastos, in Atriz Valley, next to the Galeras volcano and close to the equator. Its urban area is divided into 12 communes [46]. Figure 1 presents the location of this department in the Colombian territory.

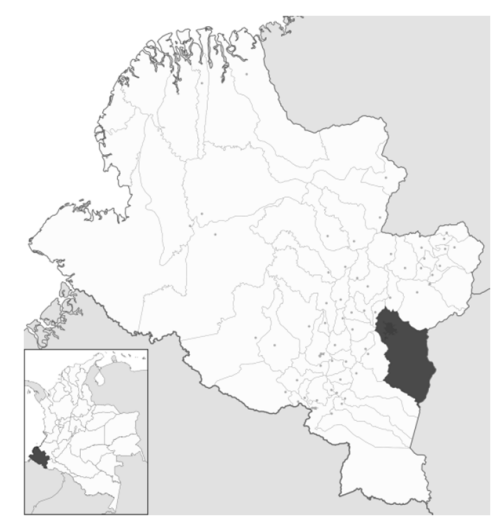

Figure 1. Municipality of Pasto, Department of Nariño, within a map of Colombia.

The composition and lower calorific value (LCV) of the waste generated in that city can be observed in Table 1; the recoverable fraction is around $89 \%$. Its solid waste management plan reported a waste PP (per capita production of waste) of $0.55 \mathrm{Kg} /$ inhab-day in the urban area [45], but this 
municipality does not have a PP indicator for the rural area. In the waste management plans of Guayatá (5126 inhab), Sabaneta (51,869 inhab), and Medellín (2,508,452 inhab) the rural values are 0.3, 0.28 , and $0.27 \mathrm{~kg} /$ inhab-day, respectively.

Since these numbers are similar in municipalities with different populations, the average among the reported values was taken for Pasto, at $0.28 \mathrm{~kg} /$ inhab-day.

Currently, the waste generated in the area under study (262 T/day) is transported to the Antanas sanitary landfill. The latter operates under an environmental license granted by the Corporación Autónoma Regional de Nariño to the Municipality of Pasto. The term is a 25-year lifespan starting in 2007.

Table 1. Lower calorific value and mass fraction of waste in the Municipality of Pasto.

\begin{tabular}{ccc}
\hline \multirow{2}{*}{ Composition } & Reference LCV & Mass Fraction in Pasto \\
\cline { 2 - 3 } & $\mathbf{( M J} / \mathbf{k g})$ & $\mathbf{( \% )}$ \\
\hline Paper and cardboard & 15.6 & 8.31 \\
Mixed food waste & 4.6 & 70 \\
Mixed plastics & 32.4 & 8.57 \\
Textiles & 18.4 & 1.41 \\
Timber & 15.4 & 0.73 \\
\hline Total LCV (MJ/kg) & & 7.66 \\
\hline
\end{tabular}

The calorific value data were taken from the study by [48]. The goal of that study was to provide technical orientation and basic technological, financial, and environmental information on Waste-to-Energy facilities. Since waste samples from Pasto could not be analyzed, said information was taken as a reference to calculate their calorific value. Based on [49], the waste of many Latin American cities present a similar physical composition. The mass fraction was directly taken from the solid waste management plan of the Municipality of Pasto [45]. The total calorific value is the result of adding the weighted columns of inferior calorific values and the mass fraction of each composition.

\subsection{Mathematical Models to Calculate Energy Recovery Potential (ERP)}

\subsubsection{Incineration:}

Equation (1) is the expression used to calculate an estimate of the electric power that can be obtained by incineration. In this case, an $26.3 \%$ efficiency was used [21]:

$$
E R P_{i}=\eta\left(M \cdot L C V_{M S W}\right) / 1000
$$

where:

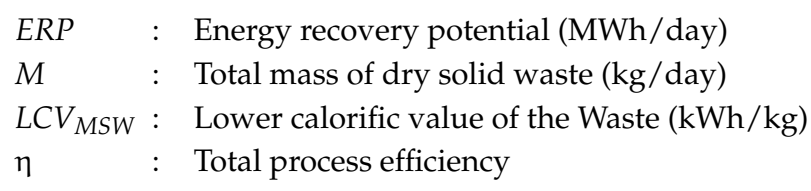

\subsubsection{Anaerobic Digestion}

The expression used to calculate electricity production potential from the total organic fraction of MSW is given in Equation (2). Based on the literature, a 26\% process efficiency was assumed for a reciprocating internal combustion engine [24]:

$$
E R P_{A D}=f \cdot M_{O F S W} \cdot Q \cdot \eta
$$

where: 
$f \quad$ : Organic matter fraction in solid waste (\%)

$M_{\text {OFSW }}$ : Generation of methane per ton of OFSW $\left(\mathrm{Nm}^{3} / \mathrm{T}\right)$

Q : Lower calorific value of biogas caused by methane $\left(\mathrm{MJ} / \mathrm{m}^{3}\right)$

This study considered a 70\% organic fraction, as presented in Table 1 . The MOFSW value set to $71 \mathrm{Nm}^{3} / \mathrm{T}$. The literature reports biogas performance values that range from 67.5 to $122 \mathrm{Nm}^{3} / \mathrm{T}$ of the organic fraction of waste [24]. In addition to the aforementioned, a 55.5\% methane content in the biogas was assumed $[16,50]$.

\subsubsection{Gasification}

Equation (3) is used to calculate the electric power that can be obtained from gasification. It employed an efficiency of $23 \%$ and a $72.51 \%$ rejection after mechanical treatment [16].

$$
E R P_{G}=0.28 \cdot G \cdot R_{f} \cdot L C V_{M S W} \cdot \eta
$$

where:

G : Tons of waste treated annually (T/year)

$R_{f}$ : Percentage of rejection after mechanical treatment

\subsubsection{Landfill Gas}

The expression to calculate methane emissions from sanitary landfills is given by Equation (4) [51-54]:

$$
Q_{C H 4}=\sum_{i=1}^{n} \sum_{j=0.1}^{1} k L_{O}\left(\frac{M_{i}}{10}\right) e^{-k t_{i j}}
$$

where:

$Q_{\mathrm{CH} 4}$ : Annual methane generation in the year of the calculation $\left(\mathrm{m}^{3} /\right.$ year $)$

$M_{i} \quad$ : Waste disposal index (T/year)

$L_{O} \quad: \quad$ Potential methane generation capacity $\left(\mathrm{m}^{3} / \mathrm{T}\right)$

$k \quad:$ Methane generation rate (1/year)

$n \quad: \quad$ (Year of the calculation)—(initial year of waste acceptance)

$i \quad:$ 1-year time increment

$j \quad:$ 0.1-year time increment

$t_{i j} \quad$ : Age of the jth section of waste mass disposed in the ith year (decimal years).

The application LandGEM (Environmental Protection Agency EPA, North Carolina, USA) was used to determine $Q_{\mathrm{CH} 4}$. The environmental parameters $\mathrm{k}$ and Lo have were from the reference in studies by Ordoñez in Colombia [52] and Scarlat in Africa [55]. They reported values of $k=0.08$ and $L_{O}=84$. Both parameters correspond to an annual precipitation over $1000 \mathrm{~mm} /$ year [56]. In Colombia, the average annual precipitations are in the order of $3240 \mathrm{~mm}$ [57]. Obtaining $Q_{\mathrm{CH} 4}$ is important because the electric power generated by the biogas depends on this variable, as described in Equation (5), for an electrical efficiency and biogas recovery of $80 \%$ and $33 \%$, respectively [58,59].

$$
E R P_{G . R .}=L C V_{b i o g a s} \cdot Q_{C H 4} \cdot \gamma \cdot \eta
$$

where:

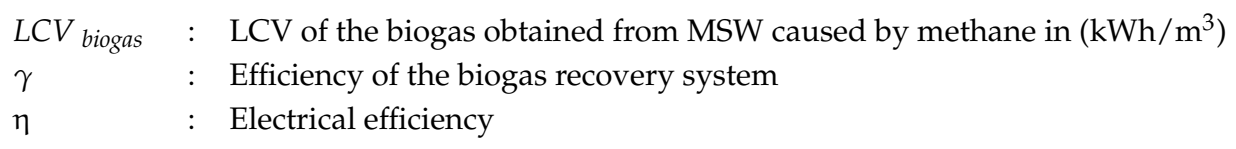

\subsection{Economic Analysis}

This analysis was conducted by evaluating the prefeasibility of the WTE plant and all the expenses. 
Table 2 details the investment expenses that each technology should consider. In this study, the selling price of electricity has been fixed at $\$ 50$ USD/MWh [60]. Power commercialization would be conducted by means of regulated electricity purchase and sale contracts. A commercialization entity would buy the power or would be able to administer bilateral contracts between generators and suppliers. For instance, the study titled Technical-economic analysis of municipal solid waste gasification to generate electricity in Brazil proposes to generate income from the sale of electric power through contracts [29]. This type of contract estimates a fixed sale price, which would be a good approximation to conduct the economic analysis. Better profits can be found in the spot market, but it would be difficult to evaluate how much could be obtained for a prefeasibility study.

Table 2. Investment, operating, and maintenance expenses.

\begin{tabular}{|c|c|c|}
\hline Technology & Investment (CAPEX) & Operation and Maintenance (OPEX) \\
\hline Incineration & $\begin{array}{l}\text { Fluidized bed incinerator: } \\
65,200 \text { USD/T-day [40] }\end{array}$ & $4 \%$ of the investment $[24]$ \\
\hline \multirow{2}{*}{ Gasification } & Fluidized bed incinerator: & Fixed expenses: $4 \%$ of the investment. \\
\hline & $3925 \mathrm{USD} / \mathrm{kW}$ to be installed [7] & Variable expenses: 4 USD/MWh [7] \\
\hline \multirow{3}{*}{ Landfill gas } & $\begin{array}{l}\text { Internal combustion engine: } \\
1,200,000 \text { USD/MW to be installed [59] }\end{array}$ & 17 USD/MWh [61] \\
\hline & $\begin{array}{l}\text { Biogas collection system: } \\
\text { 3,220,000 USD [58] }\end{array}$ & 100,000 USD/year [61] \\
\hline & $\begin{array}{l}\text { Engineering services: } \\
\text { 300,000 USD [61] }\end{array}$ & $3 \%$ of the investment in collection system [61] \\
\hline Anaerobic digestion & $\begin{array}{c}\mathrm{I}(\mathrm{USD})=101522+3500 \times[58,62-65] \\
\text { I: Investment in USDX: value in } \mathrm{kW} \text { to be installed }\end{array}$ & $16 \%$ of the investment [24] \\
\hline
\end{tabular}

Likewise, the income generated from treating a received ton of municipal solid waste (i.e., tipping fee) has been set at 10 USD/T [66], which is an average value charged by Colombian waste management companies for final waste disposal. Additionally, the income from certified emission reductions (CERs) obtained as a result of the reduction of the emission of greenhouse gases (GHG) has been assumed to be $0.51 \mathrm{USD} / \mathrm{TCO}_{2}$ [67]. The equivalent tons of $\mathrm{CO}_{2}$ have been calculated based on the annual volume of biogas, which is estimated with the application LandGEM for landfill gas in each scenario.

The levelized cost of generated electricity (LCOE) is defined as the cost per unit of energy that considers all the project's lifetime costs. It also defines a constant energy sale price during the operation of the project. The LCOE can be evaluated considering the initial investment, as well as fixed, variable, maintenance, operation, and fuel costs [68]. The expression to calculate the LCOE is shown in Equation (6):

$$
\mathrm{LCOE}=\frac{I o+\sum_{t=1}^{n} C_{t} /(1+i)^{t}}{\sum_{t=1}^{n} E_{t} /(1+i)^{t}}
$$

where:

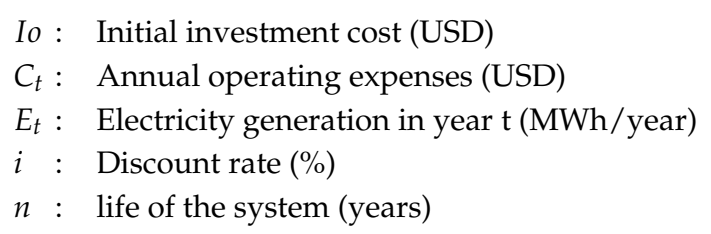

In order to evaluate the effect of the incentives mentioned above (Law 1715) on the LCOE, Equation (6) is influenced by the tax factor $\Delta$ shown in Equation (8) $[69,70]$. $\Delta$ equals 1 when incentives are not considered:

$$
\Delta=\frac{1-T_{c}-\tau *(1-T c) * \sum_{t=1}^{T^{0}} d_{t} * \gamma^{t}}{1-\tau}
$$

where: 
$T_{\mathcal{C}}: \quad$ Investment tax credit (\%)

$\tau$ : Effective corporate income tax rate (\%)

$T^{0}$ : Facility's useful life for tax purposes (years)

$d_{t}$ : Allowable depreciation charge in year $\mathrm{t}(\%)$

$\gamma:$ Discount factor $(\%)$

\section{Results}

\subsection{Estimation of Energy Recovery Potential (ERP)}

To estimate the energy recovery potential (ERP) from incineration, the LCV of the SW produced in Pasto was calculated. These values are listed in Table 1, Section 3.1. The LCV reported by [52] was considered for each type of waste. In this city, most waste comes from biodegradable organic matter, followed by plastics, paper, and cardboard. Figure 2 shows the daily electric power production of each technology from 2017 to 2022 applying the model described in Section 3.2.1. It can be observed that, by 2022 , up to $134.75 \mathrm{MWh}$ / day could be recovered from incineration. This type of power production is directly proportional to the number of inhabitants and it rises as a function of projected population growth. Regarding the latter, there is only one projection until 2020 by the National Statistics Office (DANE, for its acronym in Spanish). From that year on, the projection was made considering the percentage of linear growth between 2019 and 2020, which is $0.7 \%$ on average for different towns in the country.

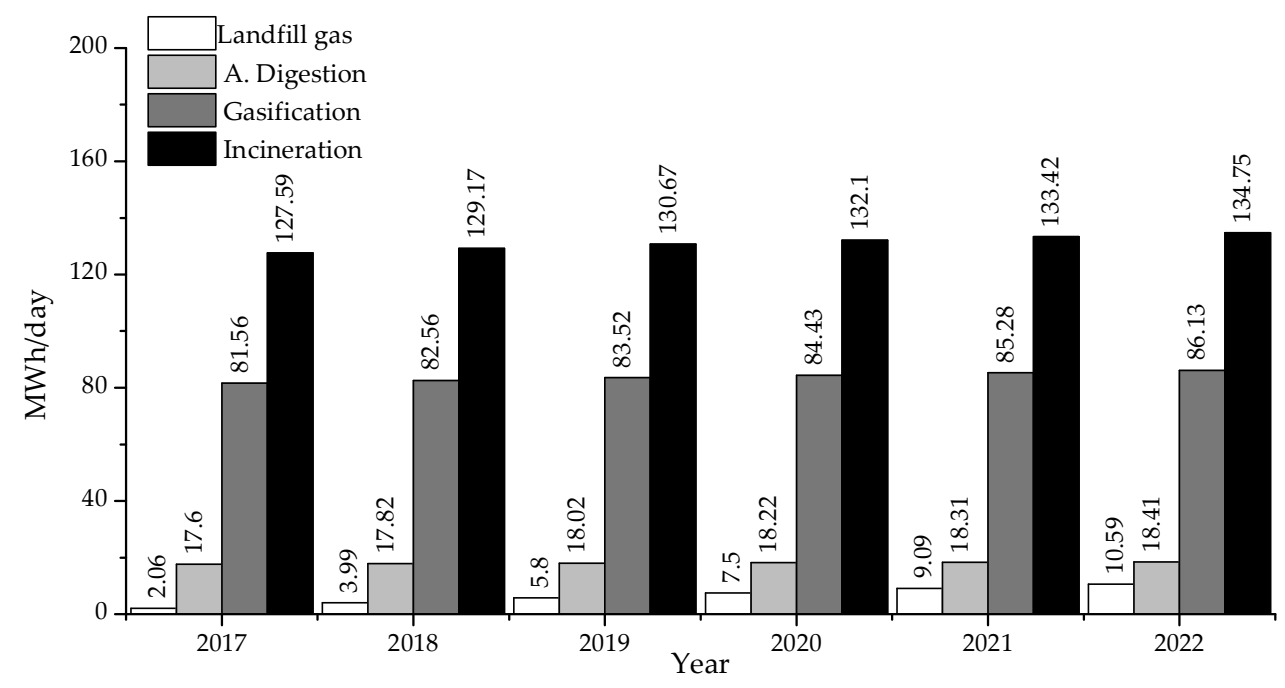

Figure 2. Electric power production in Pasto (2017-2022). Authors' own work.

Figure 2 also presents the daily production of electric power from gasification. It can be observed that by 2022 up to $86 \mathrm{MWh} /$ day could be recovered from gasification. The LCVs in Table 1 and a $72.51 \%$ recoverable mass were considered after SW mechanical treatment and sorting; losses were taken into account as well.

Regarding power generation from anaerobic digestion, an annual increase can be noted as far as $18.5 \mathrm{MWh}$ /day by 2022. The LCV of biogas used to evaluate the mathematical models of the bioconversion technologies was $5.97 \mathrm{kWh} / \mathrm{m}^{3}\left(21.51 \mathrm{MJ} / \mathrm{m}^{3}\right)$, taken from the study by [48].

Waste production per capita and number of inhabitants were used to calculate the total solid waste generated from 2016 to 2030 in each scenario, i.e., a 14-year lifespan of the landfill. The average daily methane and electric power produced by this technology are plotted in Figure 3. A peak is reached in 2031, a year after the closure of the sanitary landfill. Since it does not start operating until 2031, a continuous growth is observed in the production of both methane and electric power. The maximum amount of theoretical electric power obtained by 2031 would be 20,632 kWh/day. After that year, 
the average daily generation decreases until reaching zero in 2100. Therefore, this type of production directly depends on the amount of methane that can be recovered from waste disposed of in the sanitary landfill. The real amount of electrical energy produced by biogas from landfill is variable over time since it depends on the production of methane, the capacity of the plant, and its installed units. The production of the plant which can be seen in the shaded area that shows the actual generation of the plant over time. The electric power production of a plant is not constant, and that would be the main technical disadvantage of this alternative.

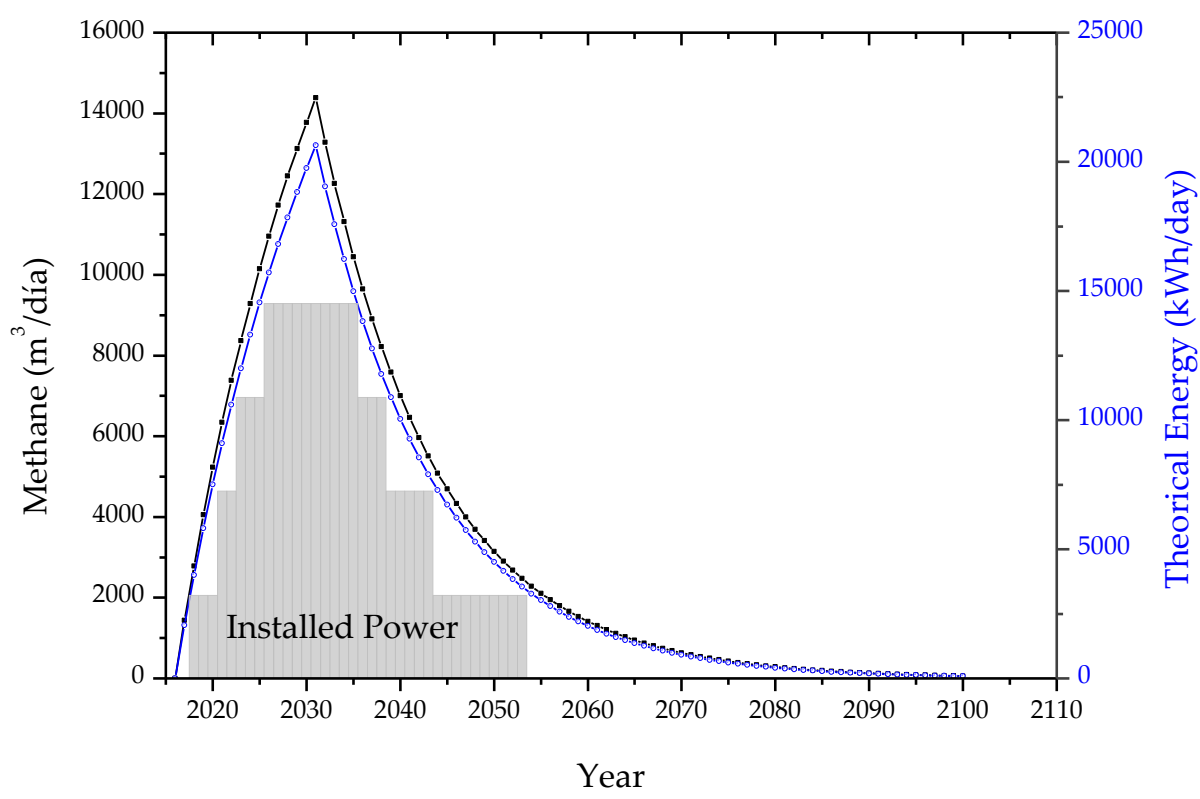

Figure 3. Electric power production from landfill gas. Authors' own work.

\subsection{Economic Analysis}

Taking into consideration the estimated ERP, each technology was financially evaluated by calculating some indicators such as internal rate of return (IRR) and levelized cost of electricity (LCOE). For this purpose, a $6.8 \%$ discount rate was used, which was determined from the CAPM [71] for a 25 -year analysis of the project $[21,40,51,58]$. Five cases were considered for the economic analysis; Cases 1 and 2 represent possibilities without tax incentives, with or without leverage. The rest of the cases include the total or partial application of the tax benefits offered by Law 1715, as detailed in Table 3. Cases 1 and 5 consider a 10 -year leverage for $50 \%$ of the investment and an $8 \%$ annual interest. In each case, CAPEX and OPEX values were taken from Table 2.

Table 3. Summary of cash flow conditions.

\begin{tabular}{cccc}
\hline Case & Loan & Accelerated Depreciation & Deductions \\
\hline 1 & Yes & No & No \\
2 & No & No & No \\
3 & No & Yes & No \\
4 & No & Yes & Yes \\
5 & Yes & Yes & Yes \\
\hline
\end{tabular}

Figure 4 summarizes the IRR evaluated for different technologies in each case. The implementation of incineration in the Municipality of Pasto requires an initial investment of \$19.5 MUSD and the maximum IRR would be $11.18 \%$. On the other hand, after an investment of \$17.7 MUSD, a maximum IRR of $7.96 \%$ would be obtained with gasification, very similar to incineration. 
Landfill gas and anaerobic digestion require initial investments of \$4 MUSD and \$2.5 MUSD and produce maximum IRRs of $13.59 \%$ and $14.27 \%$, respectively, in Case 4 . This means that a tax income deduction of up to $50 \%$ of the investment value, without considering the loan, increases the IRR above other cases.

Table 4 lists the levelized cost of generated electricity for Case 4, which exhibited the highest IRR. Regarding anaerobic digestion, given the rated capacity of the generation equipment, power production was assumed to be constant. In turn, the power production of landfill gas is proportional to the annual amount of generated methane and it rises up to a certain value after which it drops, as observed in Figure 3. However, not all the methane is recovered because the generation equipment is originally acquired for a fixed rated capacity and a 10-year lifespan.

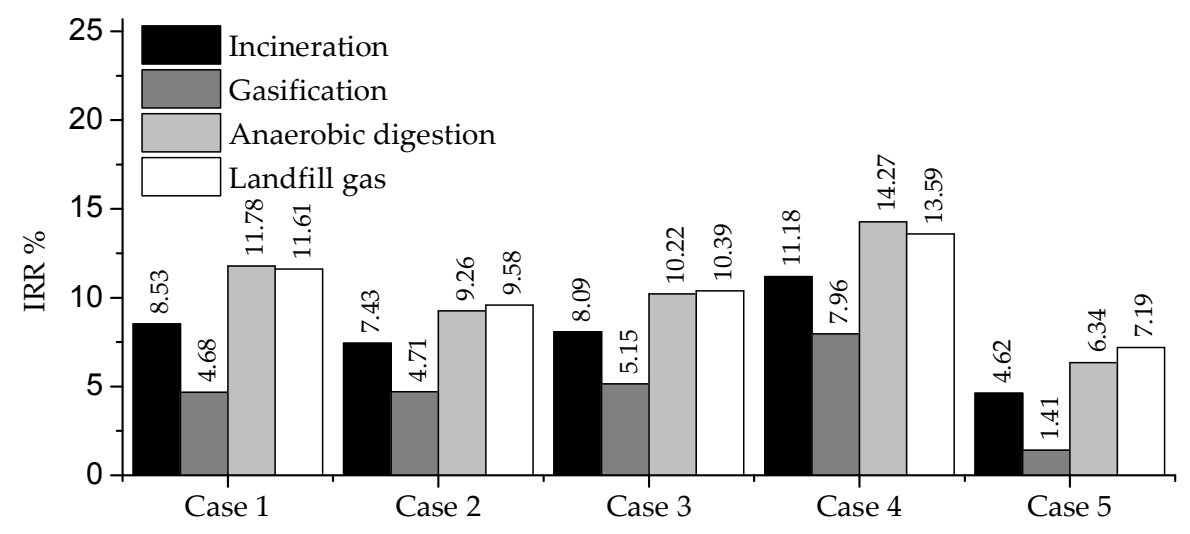

Figure 4. Internal rate of return of each technology in five cases. Authors' own work.

Table 4. Levelized cost of electricity (LCOE) of different technologies. Authors' own work.

\begin{tabular}{lcccc}
\hline Financial Indicator & Incineration & Gasification & Anaerobic Digestion & Landfill Gas \\
\hline LCOE $(\mathrm{USD} / \mathrm{MWh})$ & 38.73 & 58.17 & 108.85 & 118.83 \\
\hline
\end{tabular}

\section{Discussion}

Although the LCOE of landfill gas, anaerobic digestion, and gasification is higher than the sale price of electricity, all the technologies are financially feasible because WTE projects receive additional incomes, especially from gate fees. In addition, they benefit from special tax deductions such as those established by Law 1715 in Colombia. Table 5 summarizes the main results of each technology in Case 4. It also shows the required investment, total electricity generated throughout the lifetime of the project, tons of processed waste, NPV of tax deductions (Tax NPV), total NPV, IRR, and $\mathrm{CO}_{2}$ avoided. The high IRR values of anaerobic digestion and landfill gas are due to the lower initial investment required for said technologies.

Table 5. Summary of results in Case 4 by technology.

\begin{tabular}{lccccccc}
\hline Technology & $\begin{array}{c}\text { Total Waste } \\
\text { (T) }\end{array}$ & $\begin{array}{c}\text { Total Energy } \\
\text { (MWh) }\end{array}$ & $\begin{array}{c}\text { Investment } \\
\text { (USD) }\end{array}$ & $\begin{array}{c}\text { NPV } \\
\text { (USD) }\end{array}$ & $\begin{array}{c}\text { Tax NPV } \\
\text { (USD) }\end{array}$ & $\begin{array}{c}\text { IRR } \\
\text { (\%) }\end{array}$ & $\begin{array}{c}\mathbf{C O}_{2} \text { Avoided } \\
\text { (T) }\end{array}$ \\
\hline Landfill Gas & $1,950,000$ & 88,400 & $\$ 4,000,000$ & $\$ 1,940,000$ & $\$ 2,068,000$ & 13.59 & 688,000 \\
Incineration & $2,420,000$ & $1,080,000$ & $\$ 19,560,000$ & $\$ 5,605,000$ & $\$ 10,110,000$ & 11.18 & $1,014,691$ \\
A. Digestion & $1,690,000$ & 117,600 & $\$ 2,500,000$ & $\$ 1,050,000$ & $\$ 1,290,000$ & 14.27 & 703,695 \\
Gasification & $2,420,000$ & 706,000 & $\$ 17,660,000$ & $\$ 1,240,000$ & $\$ 9,130,000$ & 7.96 & $1,014,691$ \\
\hline
\end{tabular}

Table 5 details the environmental benefit or equivalent tons of $\mathrm{CO}_{2}$ avoided by each technology. Regarding gasification or incineration, this number refers to the tons of methane gas avoided in 25 years that could be released if the total waste was directly taken to a sanitary landfill. In the case of 
anaerobic digestion and landfill gas, it is the amount of avoided methane that organic matter produces or releases in the sanitary landfill during its lifespan.

The results in Figure 4 clearly show the positive effects of tax incentives on the IRR of all the technologies in Cases 3, 4, and 5. The highest profitability is achieved with anaerobic digestion, due to the treatment of organic waste. In second place is landfill gas because of the income generated per received ton of waste. The profitability of the remaining technologies is lower due to the high investment cost.

Incineration and gasification are the waste management options that offer greater electrical potential—substantially higher than landfill gas and anaerobic digestion—at a lower cost. Nevertheless, they are not feasible without the tax deduction incentive of Law 1715 as shown in cases 1 to 3 of Figure 4. In addition to economic considerations, waste management should include other criteria, especially environmental and social aspects.

Anaerobic digestion presents a high LCOE (108.85 USD/MWh) because of its reduced capacity to produce electric power. However, its investment cost is low, and it might be the best alternative from an environmental point of view.

Landfill gas involves low investment and operating expenses compared to thermal conversion technologies, but it produces less electric power. For that reason, its unit cost ( $\$ 118.83 \mathrm{USD} / \mathrm{MWh})$ is the highest.

In the case of Colombia, around 10 municipalities are similar to Pasto, which means that nation-wide implementation could diversify the energy matrix. Incineration (the technology that produces the highest amount of energy) is expected to produce $482 \mathrm{GWh}$ /year or landfill gas, $27.40 \mathrm{GWh} /$ year. These values represent $0.66 \%$ or $0.04 \%$, respectively, of the annual demand in Colombia in 2020.

Implementing technologies that make use of solid waste and generate electricity also contribute to addressing the following issues:

In Colombia, some sanitary landfills are near the end of their lifespan [72]. However, opening new ones is complex and requires environmental and technical licenses that are not easy to obtain. Additionally, the communities are generally opposed to approving or building them near urban areas. Furthermore, the Constitution of Colombia allows the communities to decide whether these types of projects can be carried out in their environment. This makes constructing a new sanitary landfill more difficult, even when the environmental and technical licenses can be obtained.

Energy generation from urban waste also contributes to diversifying the energy mix that, in Colombia, is based on large hydropower centers. Such plants entail problems that are reflected in the El Niño phenomenon (drought). This type of technology could reduce the impact of climate phenomena.

In remote areas or islands, the implementation of these technologies can make a significant difference. For example, in San Andres Island (Colombia) an incineration project was developed [73] to reduce the management and transportation cost of taking the waste by boat to land and then dispose of it in a sanitary landfill. In this case, the generation of electric energy helps to meet the demand on the island, which was originally satisfied with diesel generators.

Colombia is a developing country with relatively new policies and incentives for the use of solid waste to produce electric energy. In Latin America, nations like Uruguay, Peru, and Mexico have regulations that encourage these types of projects. The lessons learned in these territories could be the basis to solve common issues. However, there are other states in South America and the Caribbean that suffer from institutional weakness, as well as problems regarding the access to instruments to financially structure renewable energy projects that require both public and private investment $[10,74]$.

According to Hoornweg and Bhada-Tata in [75], approximately $42 \%$ of the waste worldwide is disposed of in sanitary landfills. In turn, the work in [76] estimates that, in $2009,80 \%$ of the waste in China was taken to the same type of facilities; in South Africa it was $90 \%$ in 2011 . On the contrary, in Europe, only $34 \%$ was sent to a landfill in 2012. These data confirm that there is a considerable international potential to make use of waste and, thus, generate electricity. 


\section{Conclusions}

This study evaluated the impact of tax benefits on WTE projects in Colombia. Said benefits positively influence the profitability of all the technologies under study. However, the LCOE of incineration and gasification are the lowest because of their greater production of electric power.

The results reveal that only anaerobic digestion and landfill gas technologies constitute viable projects in the case of traditional investment, without the fiscal incentives of Law 1715 and regardless of the use of leverage. Conversely, by including the total incentives in the economic evaluation of the projects, all the conversion technologies can achieve feasibility levels.

In the future, this research can be expanded to include the effect of MSW classification before arrival at the WTE plant. For example, for gasification and anaerobic digestion to be successful, the MSW must be segregated in color-coded containers for each type of waste at the generation site. This step supports recycling efforts and it might reduce some MSW sorting costs.

Finally, from an economic point of view, MSW incineration and gasification present more advantages. Nevertheless, since waste management is often based on other aspects than purely economic criteria (i.e., social or environmental), anaerobic digestion should not be discarded as a future option to recover energy from MSW, although it would be necessary to reduce its investment costs.

Author Contributions: Santiago Alzate-Arias, Bonie Restrepo-Cuestas, and Álvaro Jaramillo-Duque contributed with the methodology design and prepared the manuscript. Fernando Villada carried out the economical evaluation. Additionally, Alzate-Arias performed the computations and the results were analyzed by all the participants. All the authors have read and approved the final manuscript.

Conflicts of Interest: The authors declare no conflict of interest.

\section{References}

1. Soltani, A.; Sadiq, R.; Hewage, K. Selecting sustainable waste-to-energy technologies for municipal solid waste treatment: A game theory approach for group decision-making. J. Clean. Prod. 2016, 113, 388-399. [CrossRef]

2. Zhang, D.; Huang, G.; Xu, Y.; Gong, Q. Waste-to-Energy in China: Key Challenges and Opportunities. Energies 2015, 8, 14182-14196. [CrossRef]

3. Arrieta Bernate, G. Análisis de la Producción de Residuos Sólidos de Pequeños y Grandes Productores en Colombia; Comisión de Regulación de Agua Potable y Saneamiento Básico: Bogotá, Colombia, 2008; pp. 28-29.

4. Somorin, T.O.; Adesola, S.; Kolawole, A. State-level assessment of the waste-to-energy potential (via incineration) of municipal solid wastes in Nigeria. J. Clean. Prod. 2017, 164, 804-815. [CrossRef]

5. Byamba, B.; Ishikawa, M. Municipal Solid Waste Management in Ulaanbaatar, Mongolia: Systems Analysis. Sustainability 2017, 9, 896. [CrossRef]

6. Ouda, O.K.M.; Cekirge, H.M.; Raza, S.A.R. An assessment of the potential contribution from waste-to-energy facilities to electricity demand in Saudi Arabia. Energy Convers. Manag. 2013, 75, 402-406. [CrossRef]

7. Hadidi, L.A.; Omer, M.M. A financial feasibility model of gasification and anaerobic digestion waste-to-energy (WTE) plants in Saudi Arabia. Waste Manag. 2017, 59, 90-101. [CrossRef] [PubMed]

8. Mbuligwe, S.E.; Kassenga, G.R. Feasibility and strategies for anaerobic digestion of solid waste for energy production in Dar es Salaam city, Tanzania. Resour. Conserv. Recycl. 2004, 42, 183-203. [CrossRef]

9. Song, J.; Sun, Y.; Jin, L. PESTEL analysis of the development of the waste-to-energy incineration industry in China. Renew. Sustain. Energy Rev. 2017, 80, 276-289. [CrossRef]

10. Moreno Figueredo, C. Leyes para las Energías renovables en América Latina y el Caribe. Available online: http://www.cubasolar.cu/Biblioteca/Energia/Energia56/HTML/Articulo05.htm (accessed on 4 July 2017).

11. Congreso de Chile. Ley Introduce Modificaciones a la Ley General de Servicios Eléctricos Respecto de la Generación de Energía Eléctrica con Fuentes de Energías Renovables no Convencionales; Ministerio de Energía: Santiago de Chile, Chile, 2008.

12. Senado y Cámara de Diputados de Argentina. Ley 26.190 Regimen de Fomento Nacional Para el Uso de Fuentes Renovables de Energía Destinada a la Producción de Energía Eléctrica; Ministerio de Energía y Minería: Buenos Aires, Argentina, 2006. 
13. Niño, G.; Mendívil, A.; Velasco, A.; García, G. Marco jurídico de las energías renovables en México; CEMDA: Ciudad de México, Mexico, 2017; p. 9.

14. Congreso de Colombia. Ley No 1715 Por Medio de la Cual se Regula la Integración de las Energías Renovables no Convencionales al Sistema Energético Nacional; UPME: Bogotá, Colombia, 2014.

15. Superintendencia de Servicios Públicos Domiciliarios República de Colombia. Disposición Final de Residuos Sólidos_Informe Nacional, 7th ed.; Departamento Nacional de Planeación: Bogotá, Colombia, 2015; pp. 15-16, 46-50.

16. Fernández-González, J.M.; Grindlay, A.L.; Serrano-Bernardo, F.; Rodríguez-Rojas, M.I.; Zamorano, M. Economic and environmental review of Waste-to-Energy systems for municipal solid waste management in medium and small municipalities. Waste Manag. 2017, 67, 360-374. [CrossRef] [PubMed]

17. Tan, S.T.; Ho, W.S.; Hashim, H.; Lee, C.T.; Taib, M.R.; Ho, C.S. Energy, economic and environmental (3E) analysis of waste-to-energy (WTE) strategies for municipal solid waste (MSW) management in Malaysia. Energy Convers. Manag. 2015, 102, 111-120. [CrossRef]

18. Ofori-Boateng, C.; Lee, K.T.; Mensah, M. The prospects of electricity generation from municipal solid waste (MSW) in Ghana: A better waste management option. Fuel Process. Technol. 2013, 110, 94-102. [CrossRef]

19. Aga, O.; Ouda, O.K.M.; Raza, S.A. Investigating waste to energy potential in the eastern region, Saudi Arabia. In Proceedings of the 2014 International Conference on Renewable Energies for Developing Countries (REDEC), Beirut, Lebanon, 26-27 November 2014.

20. Chaliki, P.; Psomopoulos, C.S.; Themelis, N.J. WTE plants installed in European cities: A review of success stories. Manag. Environ. Qual. Int. J. 2016, 27, 606-620. [CrossRef]

21. Kalogirou, E.N. Waste-to-Energy Technologies and Global Applications; CRC Press: Boca Raton, FL, USA, 2017.

22. Abd Kadir, S.A.S.; Yin, C.-Y.; Rosli Sulaiman, M.; Chen, X.; El-Harbawi, M. Incineration of municipal solid waste in Malaysia: Salient issues, policies and waste-to-energy initiatives. Renew. Sustain. Energy Rev. 2013, 24, 181-186. [CrossRef]

23. Poletto Filho, J.A. Viabilidade Energética E Econômica Da Incineração De Resíduo Sólido Urbano Considerando a Segregação Para Reciclagem. Master's Thesis, Universidade Estadual Paulista, São Paulo, Brazil, 2008.

24. Gómez, A.; Zubizarreta, J.; Rodrigues, M.; Dopazo, C.; Fueyo, N. Potential and cost of electricity generation from human and animal waste in Spain. Renew. Energy 2010, 35, 498-505. [CrossRef]

25. Menikpura, S.N.M.; Sang-Arun, J.; Bengtsson, M. Assessment of environmental and economic performance of Waste-to-Energy facilities in Thai cities. Renew. Energy 2016, 86, 576-584. [CrossRef]

26. Fazeli, A.; Bakhtvar, F.; Jahanshaloo, L.; Che Sidik, N.A.; Bayat, A.E. Malaysia's stand on municipal solid waste conversion to energy: A review. Renew. Sustain. Energy Rev. 2016, 58, 1007-1016. [CrossRef]

27. Kalyani, K.A.; Pandey, K.K. Waste to energy status in India: A short review. Renew. Sustain. Energy Rev. 2014, 31, 113-120. [CrossRef]

28. IPSE. En Necoclí los Residuos de Madera se Convierten en Importante Recurso energético. Available online: http:/ / www.ipse.gov.co/transparencia-y-acceso-a-informacion-publica/informacion-de-interes2/ noticias / 446-en-necocli-los-residuos-de-madera-se-convierten-en-importante-recurso-energetico (accessed on 23 January 2018).

29. Luz, F.C.; Rocha, M.H.; Lora, E.E.S.; Venturini, O.J.; Andrade, R.V.; Leme, M.M.V.; del Olmo, O.A. Techno-economic analysis of municipal solid waste gasification for electricity generation in Brazil. Energy Convers. Manag. 2015, 103, 321-337. [CrossRef]

30. Thakare, S.; Nandi, S. Study on Potential of Gasification Technology for Municipal Solid Waste (MSW) in Pune City. Energy Procedia 2015, 90, 509-517. [CrossRef]

31. Xu, P.; Jin, Y.; Cheng, Y. Thermodynamic Analysis of the Gasification of Municipal Solid Waste. Engineering 2017, 3, 416-422. [CrossRef]

32. Ranieri, L.; Mossa, G.; Pellegrino, R.; Digiesi, S. Energy Recovery from the Organic Fraction of Municipal Solid Waste: A Real Options-Based Facility Assessment. Sustainability 2018, 10, 368. [CrossRef]

33. Khelidj, B.; Abderezzak, B.; Kellaci, A. Biogas production potential in Algeria: Waste to energy opportunities. In Proceedings of the 2012 International Conference on Renewable Energies for Developing Countries (REDEC), Beirut, Lebanon, 28-29 November 2012. 
34. GICON. Valorización energética de los resiudos a través de tratamientos biológicos-Tecnología de biogás. In Proceedings of the 1a Conferencia Panamericana-Waste to Energy 2016, Medellín, Colombia, 10-11 March 2016; pp. 41-50.

35. Kothari, R.; Pandey, A.K.; Kumar, S.; Tyagi, V.V.; Tyagi, S.K. Different aspects of dry anaerobic digestion for bio-energy: An overview. Renew. Sustain. Energy Rev. 2014, 39, 174-195. [CrossRef]

36. Jiang, J.; Sui, J.; Wu, S.; Yang, Y.; Wang, L. Prospects of anaerobic digestion technology in China. Tsinghua Sci. Technol. 2007, 12, 435-440. [CrossRef]

37. Coimbra-Araújo, C.H.; Mariane, L.; Júnior, C.B.; Frigo, E.P.; Frigo, M.S.; Araújo, I.R.C.; Alves, H.J. Brazilian case study for biogas energy: Production of electric power, heat and automotive energy in condominiums of agroenergy. Renew. Sustain. Energy Rev. 2014, 40, 826-839. [CrossRef]

38. Chakraborty, M.; Sharma, C.; Pandey, J.; Gupta, P.K. Assessment of energy generation potentials of MSW in Delhi under different technological options. Energy Convers. Manag. 2013, 75, 249-255. [CrossRef]

39. Fazeli, A.; Bakhtvar, F.; Jahanshaloo, L.; Azwadi, N.; Sidik, C.; Bayat, A.E.; Ouda, O.K.M.; Raza, S.A.; Nizami, A.S.; Rehan, M.; et al. santy_Waste to energy potential: A case study of Saudi Arabia. Renew. Sustain. Energy Rev. 2016, 61, 328-340. [CrossRef]

40. Zhao, X.; Jiang, G.; Li, A.; Wang, L. Economic analysis of waste-to-energy industry in China. Waste Manag. 2016, 48, 604-618. [CrossRef] [PubMed]

41. Tsai, W.T. Bioenergy from landfill gas (LFG) in Taiwan. Renew. Sustain. Energy Rev. 2007, 11, 331-344. [CrossRef]

42. Yechiel, A.; Shevah, Y. Optimization of energy generation using landfill biogas. J. Energy Storage 2016, 7, 93-98. [CrossRef]

43. Borda Perez, C.G. Biogás: Una Alternativa Energética Para los Rellenos Sanitarios Urbanos y un Beneficio Mitigador de Cambio Climático. Bachelor's Thesis, Universidad Militar Nueva Granada, Bogotá, Colombia, 2016.

44. Energía 16. En Cúcuta construyen una planta para generar energías con desechos sólidos. Available online: https:/ / www.energia16.com/en-cucuta-construyen-una-planta-para-generar-energiascon-desechos-solidos/ (accessed on 15 December 2017).

45. Delgado Guerrero, R. Plan de Gestión Integral de Residuos Sólidos PGIRS Municipio de Pasto; Alcaldia de Pasto: Pasto, Colombia, 2007; pp. 63-70.

46. Alcaldía de Pasto. Información General-Pasto-Nariño-Colombia. Available online: http://www.pasto.gov. co/index.php/nuestro-municipio (accessed on 10 October 2017).

47. Posada Hernandez, G.J. Agrupación de Municipios Colombianos Según Características de Ruralidad. Ph.D. Thesis, Universidad Nacional de Colombia, Bogotá, Colombia, 2010.

48. Themelis, N.J.; Elena, M.; Barriga, D.; Estevez, P.; Velasco, M.G. Guidebook for the Application of Waste to Energy Technologies in Latin America and the Caribbean; Earth Engineering Center, Columbia University: New York, NY, USA, 2013.

49. Leckner, B. Process aspects in combustion and gasification Waste-to-Energy (WtE) units. Waste Manag. 2015, 37, 13-25. [CrossRef] [PubMed]

50. Murphy, J.D.; McCarthy, K. The optimal production of biogas for use as a transport fuel in Ireland. Renew. Energy 2005, 30, 2111-2127. [CrossRef]

51. Mambeli Barros, R.; Tiago Filho, G.L.; da Silva, T.R. The electric energy potential of landfill biogas in Brazil. Energy Policy 2014, 65, 150-164. [CrossRef]

52. Ordoñez, M.D.C.O. Evaluación de la Generación de Biogas en Rellenos Sanitarios en Colombia en el Marco del Protocolo de Kyoto. Doctoral Dissertation, Universidad Tecnológica de Pereira, Pereira, Colombia, 2011.

53. Mustafa, S.S.; Mustafa, S.S.; Mutlag, A.H. Kirkuk municipal waste to electrical energy. Int. J. Electr. Power Energy Syst. 2013, 44, 506-513. [CrossRef]

54. Aguilar-Virgen, Q.; Taboada-González, P.; Ojeda-Benítez, S. Analysis of the feasibility of the recovery of landfill gas: A case study of Mexico. J. Clean. Prod. 2014, 79, 53-60. [CrossRef]

55. Scarlat, N.; Motola, V.; Dallemand, J.F.; Monforti-ferrario, F.; Mofor, L. Evaluation of energy potential of Municipal Solid Waste from African urban areas. Renew. Sustain. Energy Rev. 2015, 50, 1269-1286. [CrossRef]

56. Panesso, A.F.; Cadena, J.A.; Mora, J.J.; Ordoñez, M.C. Estudio del biogás captado en un relleno sanitario para su posible utilización como combustible primario en la generación de energía eléctrica. Ide@s Concyteg $2012,7,1170-1182$. 
57. Banco Mundial. Promedio Detallado de Precipitaciones (mm Anuales). Available online: https://datos. bancomundial.org/indicador/AG.LND.PRCP.MM?view=map (accessed on 13 November 2017).

58. Cadena, J.; Pérez, S.; Mora, J. Análisis de viabilidad financiera de una central de generación de energía eléctrica a partir del biogás de vertedero. Sci. Tech. Año XVI 2012, 51, 1-7.

59. Bove, R.; Lunghi, P. Electric power generation from landfill gas using traditional and innovative technologies. Energy Convers. Manag. 2006, 47, 1391-1401. [CrossRef]

60. UPME. Plan de Expansión e Integración de Energías Renovables en el Sistema Interconectado Nacional-SIN; UPME: Bogotá, Colombia, 2016; p. 8.

61. Leme, M.M.V.; Rocha, M.H.; Lora, E.E.S.; Venturini, O.J.; Lopes, B.M.; Ferreira, C.H. Techno-economic analysis and environmental impact assessment of energy recovery from Municipal Solid Waste (MSW) in Brazil. Resour. Conserv. Recycl. 2014, 87, 8-20. [CrossRef]

62. Walla, C.; Schneeberger, W. The optimal size for biogas plants. Biomass Bioenergy 2008, 32, 551-557. [CrossRef]

63. IDAE. Biomasa: Digestores Anaerobios; IDAE, Ed.; IDAE: Madrid, Spain, 2007.

64. Farming Futures. Focus on: Farm anaerobic. Farming Futur. 2009, 17, 4.

65. Ace. Energy Farms-Anaerobic Digestion; Academy of Champions for Energy: Brussels, Belgium, 2011.

66. Emvarias-Grupo EPM. Información Tarifaria. Available online: http://www.emvarias.com. co/SitePages / Forms / AllPages.aspx?RootFolder=\%2FSitePages\%2FInformacionTarifaria2016\& FolderCTID=0x012000FD1E4E0A8E3F4C4BA17E4FA04F9A9ECD\&View=\%7B461FC4AA-67A3-4E44B029-3BA5F40C764D\%7D (accessed on 3 July 2017).

67. Commodity Exchange Bratislavava. Carbon place. Available online: http://www.carbonplace.eu/infocommodities-CER (accessed on 10 October 2017).

68. MinMinas. Energía Eléctrica-Ministerio de Minas y Energía. Available online: https:/ /www.minminas.gov. co/energias-renovables-no-convencionales (accessed on 10 August 2017).

69. Reichelstein, S.; Yorston, M. The prospects for cost competitive solar PV power. Energy Policy 2013, 55, 117-127. [CrossRef]

70. Castillo Ramírez, A.; Villada, M.; Toro, M.; Barrientos, J. Costos nivelados de generación de electricidad. AIE UDEA 2014, 13, 18-23.

71. Sánchez, J.H. The discount rate in emerging countries-application of the Colombian case. Rev. EAN 2010, 69, 120-134.

72. El Colombiano. Basuras, Una Bomba de Tiempo en Colombia; El Colombiano: Medellín, Colombia, 2017.

73. Semana. El Fallo Que Busca Salvar a San Andrés de Ahogarse en su Basura; Semana: Bogotá, Colombia, 2017.

74. Agencia EFE. Olade Destaca "sólida" Incorporación de Energías Renovables en Latinoamérica; Agencia EFE: Quito, Ecuador, 2018.

75. Hoornweg, D.; Bhada-Tata, P. What a Waste: A Global Review of Solid Waste Management; Urban Development Series Knowledge Papers; World Bank: Washington, DC, USA, 2012.

76. Muvundika, A.B. Development of a Framework for Assessing Sustainability Benefits of Landfill Gas Clean Development Mechanism (CDM) Projects. Doctoral Dissertation, University of Central Lancashire, Preston, UK, 2015.

(C) 2018 by the authors. Licensee MDPI, Basel, Switzerland. This article is an open access article distributed under the terms and conditions of the Creative Commons Attribution (CC BY) license (http://creativecommons.org/licenses/by/4.0/). 